\title{
Electrical Properties of Sb Doped Diamond Films
}

\author{
$S \mathrm{~b}$ 添加ダイヤモンド膜の電気的特性
}

Tohru Mizushima, Satoshi Suzuki, Takuya Kato, Noritaka Shikase Hironaga Shindo, Tadashi Shiraishi, Takashi Inushima and *Hideomi koinuma Faculty of Engineering., Tokai University. *Tokyo Institute of Technology.

1117 Ki takaname, Hiratsuka, Kanagawa, 259-12 Japan

( Accepted for publication 17 November 1994)

\section{1. 研究目的}

ダイヤモンドは電気的、光学的、熱的に優れた物性を 有しており、デバイスへの応用が試みられている。しか しながら, a s-d e pos i t e d CVD ダイヤ モンド膜には表面に電気伝導層が存在しており、この発 生機構が未解明であることや、不純物をドープすること によって得られる半導体ダイヤモンド膜はキャリア移動 度が低いことなど不明な点が多い。不純物として S bを 添加するこによって、得られた試料の電気的特性につい て調査することを目的とした。

\section{2 . 実験}

製膜に使用した装置の概略図を F i g u r e 1 に示 す。熱フィラメントは石英管チャンバー上部フランジよ り設置した。2枚の S b 板は、両端から導入したステン レス製棒の先端に、フィラメント位置から同じ距離に設 置し、ダイヤモンド膜の堆積中にフィラメントの熱によ り蒸発させ添加を行った。また、 $S$ i 基板横と S b 板横 に設置した熱電対により、それぞれの温度を測定した。 反応ガスとしては水素とエチルアルコールの混合ガスを 用い、原料濃度は $0.7 \%$ とした。

3 . 結果亡考察

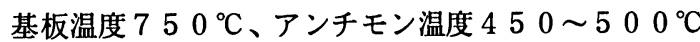
で添加することによって得られた膜の結晶学的評価を行 なうためにラマンソペクトル、X線回折、SEM像観察 を行った。この結果から、II a 型ダイヤモンド膜との違 いはみられなかった。

電気的特性を調查するために、膜上に直径 $0.6 \mathrm{~mm}$ の A u 蒸着した試料を用い、V a n d e r P a u w 法によりホール測定を行った。キャャリア移動度一温度特 性をF i g u r e 2 に示す。373 [K] 以下、及び 423 [ $\mathrm{K}$ ] 以上の温度領域で $\mathrm{n}$ 型の特性が得られた。 また、2つのピークが存在することから、この試料を流 れる電流パスは $2 つ$ 存在すると考えられる。このような 移動度一温度特性のもとでの、高温域における抵抗率一 温度特性は、直線的であったので活性化エネルギーを調 べたところ、約 0.15 [ e V ] であった。このような 電流パスについて調查するために、比抵抗一温度特性の 膜厚依存性の測定結果を F i g u r e 3 に示す。膜厚 の増加にたいして比抵抗が増加することから、バルクと いうよりむむしろ、F i g u r e 4 に示したように表 面と界面での現象が主であると思われる。

\section{4. まとめ}

$\mathrm{V}$ a n d e r P a u w法によるホール測定から得ら れた移動度一温度特性の結果から、2つの電流パスが考 えられる。これは、比抵抗一温度特性の膜厚依存性から、 ダイヤモンド表面とダイヤモンド／S i 界面でのものと 思われる。

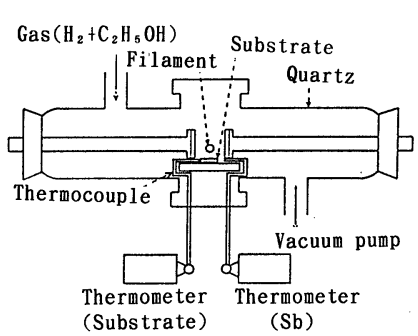

Fig. 1. 実験装置概略図

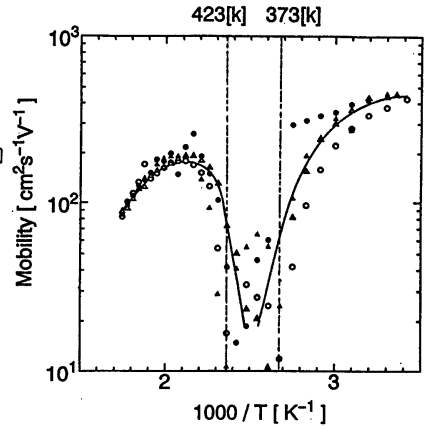

Fig. 2. キャリア移動度の温度特性 423[K] 373[K

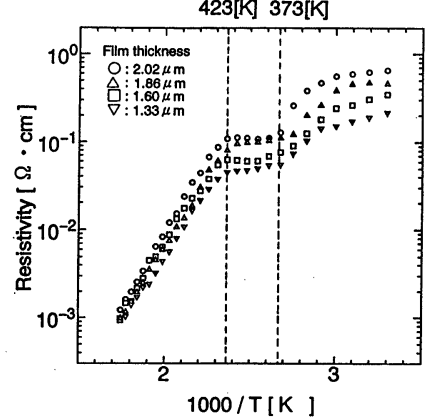

Fig. 3. 比抵抗一温度特性の膜厚依存性

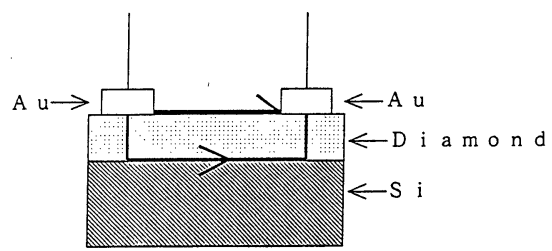

Fig. 4. 表面と界面の電流パスのモデル

'94 SAS Intelligent Symposium 